Celebes Education Review
http://journal.lldikti9.id/CER/index
Vol 2 No, 1 April 2020
p-ISSN: $\underline{\mathbf{2 6 5 6 - 7 3 8 5} \text { dan e-ISSN: 2684-7124 }}$

\title{
Bimbingan Pengawas Berkelanjutan dalam Mewujudkan Pendidikan Karakter Bangsa dalam Kegiatan Belajar Mengajar Penjaskes
}

\author{
H. Anis Pacinongi \\ UPTD Kab. Sidrap, Dinas Pendidikan Propinsi Sulawesi Selatan \\ Email: anispacinongi@yahoo.co.id \\ Andi Asrifan \\ FKIP, Universitas Muhammadiyah Sidenreng Rappang \\ Email: andiasrifan@gmail.com
}

\section{Artikel history:}

Received; 15-03-2020

Revised: 18-03-2020

Accepted; 28-03-2020

\begin{abstract}
The objectives to be achieved in this study are 1) Improving the understanding ability of the Physical Education teachers in developing the RPP containing the nation's character; and, 2) Increase the implementation of the value of national character development in teaching and learning activities. The data on the results of the RPP assessment that includes the national character in the first cycle shows that the achievement of the average score of the Penjaskes subject lesson is 30 (not good), and in the cycle II obtained an average score of 43 (very good). Thus the two RPPs have been categorized very well. Student activities in learning activities that embody the national character value in the first cycle reached an average value of 75 , and in the second cycle reached an average value of 91 , there was a significant increase in the value of 16 from the first cycle. -national character development values in the first cycle, it seems that there are not many indicators of the nation's character development values that can be realized. The observational data shows that from the 5 indicators of the nation's character development values studied, $75 \%$ of the new health education subjects emerged, and $91 \%$ of the implementation of the second cycle achieved an increase of $16 \%$.
\end{abstract}

Abstrak. Tujuan yang ingin dicapai dalam penelitian ini adalah 1) Meningkatkan kemampuan pemahaman guru penjaskes dalam menyusun RPP memuat karakter bangsa; dan, 2) Meningkatkan keterlaksanaan nilai pembangunan karakter bangsa dalam kegiatan belajar mengajar. Data hasil penilaian RPP yang memuat karakter kebangsaan pada siklus I menunjukkan bahwa pencapaian skor nilai rata-rata RPP mapel 
penjaskes adalah 30 (kurang baik); dan pada siklus II memperoleh skor nilai rata-rata 43 (sangat baik). Dengan demikian kedua RPP tersebut sudah dikatagorikan sangat baik. Aktivitas siswa dalam kegiatan pembelajaran yang mewujudkan nilai karakter bangsa pada siklus I mencapai nilai rata-rata sebesar 75, dan pada siklus II mencapai nilai rata-rata sebesar 91, terdapat peningkatan nilai yang cukup signifikan sebesar 16 dari siklus I. Dilihat dari data keterlaksanaan nilai-nilai pembangunan karakter bangsa pada siklus I, terlihat belum banyak indikator nilai-nilai pembangunan karakter bangsa yang dapat diwujudkan. Data hasil observasi menunjukkan bahwa dari 5 indikator nilai-nilai pembangunan karakter bangsa yang diteliti, dalam mata pelajaran penjaskes baru muncul 75\%, dan pada pelaksanaan siklus II telah tercapai 91\%, terdapat peningkatan ketercapaian sebesar $16 \%$.

\section{Keywords:}

Pembangunan

Karakter Bangsa.

Proses Belajar

Mengajar.

Guru
Coresponden author:

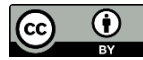

artikel dengan akses terbuka dibawah lisensi CC BY-4.0

\section{PENDAHULUAN}

Rencana Pelaksanaan Pembelajaran (RPP) adalah instrument perencanaan yang lebih spesifik dari silabus. Rencana Pelaksanaan Pembelajaran ini dibuat untuk memandu guru dalam mengajar agar tidak melebar jauh dari tujuan pembelajaran.

Dengan melihat pentingnya penyusunan perencanaan pembelajaran ini, guru semestinya tidak mengajar tanpa adanya rencana. Namun sayang perencanaan pembelajaran yang mestinya dapat diukur oleh kepala sekolah ini, tidak dapat diukur oleh kepala sekolah karena hanya direncanakan dalam pikiran sang guru saja. Akibatnya kepala sekolah sebagai pembuat kebijakan di sekolah tidak dapat mengevaluasi kinerja guru secara akademik. Kinerja yang dapat dilihat oleh kepala sekolah hanyalah kehadiran tatap muka, tanpa mengetahui apakah kemampuan guru dalam mengelola pembelajaran sudah sesuai dengan harapan atau belum, atau sudahkah kompetensi dasar yang harus dikuasai oleh siswa terkuasai dengan benar.

Pembangunan karakter bangsa yang sudah diupayakan dengan berbagai bentuk, hingga saat ini belum terlaksana dengan optimal. Hal itu tecermin dari kesenjangan sosialekonomi-politik yang masih besar, kerusakan lingkungan yang terjadi di berbagai di seluruh pelosok negeri, masih terjadinya ketidakadilan hukum, pergaulan bebas dan pornografi yang terjadi di kalangan remaja, kekerasan dan kerusuhan, korupsi yang dan merambah pada semua sektor kehidupan masyarakat. Saat ini banyak dijumpai tindakan anarkis, konflik sosial, penuturan bahasa yang buruk dan tidak santun, dan ketidaktaataan berlalu lintas. Masyarakat Indonesia yang terbiasa santun dalam berperilaku, melaksanakan musyawarah mufakat dalam menyelesaikan masalah, mempunyai kearifan lokal yang kaya dengan pluralitas, serta bersikap toleran dan gotong royong mulai cenderung berubah menjadi hegemoni kelompok-kelompok yang saling mengalahkan dan berperilaku tidak jujur. Semua itu menegaskan bahwa terjadi 
ketidakpastian jati diri dan karakter bangsa yang bermuara pada (1) disorientasi dan belum dihayatinya nilai-nilai Pancasila sebagai filosofi dan ideologi bangsa, (2) keterbatasan perangkat kebijakan terpadu dalam mewujudkan nilai-nilai esensi Pancasila, (3) bergesernya nilai etika dalam kehidupan berbangsa dan bernegara, (4) memudarnya kesadaran terhadap nilai-nilai budaya bangsa, (5) ancaman disintegrasi bangsa, dan (6) melemahnya kemandirian bangsa.

Memperhatikan situasi dan kondisi karakter bangsa yang memprihatinkan tersebut, pemerintah mengambil inisiatif untuk memprioritaskan pembangunan karakter bangsa. Pembangunan karakter bangsa seharusnya menjadi arus utama pembangunan nasional. Artinya, setiap upaya pembangunan harus selalu dipikirkan keterkaitan dan dampaknya terhadap pengembangan karaker. Hal itu tecermin dari misi pembangunan nasional yang memosisikan pendidikan karakter sebagai misi pertama dari delapan misi guna mewujudkan visi pembangunan nasional, sebagaimana tercantum dalam Rencana Pembangunan Jangka Panjang Nasional Tahun 2005-2025 (Undang-Undang Republik Indonesia Nomor 17 Tahun 2007), yaitu terwujudnya karakter bangsa yang tangguh, kompetitif, berakhlak mulia, dan bermoral berdasarkan Pancasila, yang dicirikan dengan watak dan prilaku manusia dan masyarakat Indonesia yang beragam, beriman dan bertakwa kepada Tuhan Yang Maha Esa, berbudi luhur, bertoleran, bergotongroyong, berjiwa patriotik, berkembang dinamis, dan berorientasi ipteks.

Pembangunan karakter bangsa memiliki urgensi yang sangat luas dan bersifat multidimensional. Sangat luas karena terkait dengan pengembangan multiaspek potensi-potensi keunggulan bangsa dan bersifat multidimensional karena mencakup dimensi-dimensi kebangsaan yang hingga saat ini sedang dalam proses "menjadi". Dalam hal ini dapat juga disebutkan bahwa (1) karakter merupakan hal sangat esensial dalam berbangsa dan bernegara, hilangnya karakter akan menyebabkan hilangnya generasi penerus bangsa; (2) karakter berperan sebagai "kemudi" dan kekuatan sehingga bangsa ini tidak terombang-ambing; (3) karakter tidak datang dengan sendirinya, tetapi harus dibangun dan dibentuk untuk menjadi bangsa yang bermartabat. Selanjutnya, pembangunan karakter bangsa akan mengerucut pada tiga tataran besar, yaitu (1) untuk menumbuhkan dan memperkuat jati diri bangsa, (2) untuk menjaga keutuhan Negara Kesatuan Republik Indonesia (NKRI), dan (3) untuk membentuk manusia dan masyarakat Indonesia yang berakhlak mulia dan bangsa yang bermartabat.

Pembangunan karakter bangsa harus diaktualisasikan secara nyata dalam bentuk aksi nasional dalam rangka memantapkan landasan spiritual, moral, dan etika pembangunan bangsa sebagai upaya untuk menjaga jati diri bangsa dan memperkukuh persatuan dan kesatuan bangsa dalam naungan NKRI. Pembangunan karakter bangsa harus dilakukan melalui pendekatan sistematik dan integratif dengan melibatkan keluarga; satuan pendidikan; pemerintah; masyarakat termasuk teman sebaya, generasi muda, lanjut usia, media massa, pramuka, organisasi kemasyarakatan, organisasi politik, organisasi profesi, lembaga swadaya masyarakat; kelompok strategis seperti elite struktural, elite politik, wartawan, budayawan, agamawan, tokoh adat, serta tokoh masyarakat. Adapun strategi pembangunan karakter dapat dilakukan melalui sosialisasi, pendidikan, pemberdayaan, pembudayaan, dan kerja sama dengan memperhatikan kondisi lingkungan dan kebutuhan masyarakat serta pendekatan multidisiplin yang tidak menekankan pada indoktrinasi.

Pembelajaran Aktif, inovatif, Kreatif, Efektif, dan Menyenangkan, merupakan proses pembelajaran guru harus menciptakan suasana sedemikian rupa sehingga siswa aktif bertanya, mempertanyakan, dan mengemukakan gagasan. Belajar memang merupakan suatu proses aktif dari si pembelajar dalam membangun pengetahuannya, bukan proses pasif yang hanya menerima kucuran ceramah guru tentang pengetahuan. Jika pembelajaran tidak memberikan kesempatan kepada siswa untuk berperan aktif, maka pembelajaran tersebut bertentangan 
dengan hakikat belajar. Peran aktif dari siswa sangat penting dalam rangka pembentukan generasi yang kreatif, yang mampu menghasilkan sesuatu untuk kepentingan dirinya dan orang lain. Dengan demikian melalui penerapan pendakatan nilai karakter bangsa siswa didik untuk gemar membaca, belajar dengan sungguh-sungguh, mengerjakan sesuatu pekerjaan dengan sebaik mungkin, berupaya mendapatkan hasil terbaik, bekerjasama dengan sesama teman dan hal-hal positip lainnya yang semuanya memiliki keterkaitan dengan indikator nilai-nilai pembangunan karakter bangsa.

Berdasarkan kenyataan di atas penulis mencoba mengadakan penelitian tindakan sekolah untuk mengetahui efektivitas penerapan pendekatan dengan mewujudkan nilai karakter bangsa dalam kegiatan belajar mengajar (KBM) di SMK Negeri 1 Sidenreng serta kaitnya dengan pembangunan karakter bangsa.

\section{METODE}

Metode yang digunakan dalam penelitian ini adalah metode Penelitian Tindakan Sekolah (PTS) yang dilaksanakan di SMK Negeri 1 Sidenreng, Kabupaten Sidenreng Rappang semester ganjil tahun pelajaran 2014/2015. Populasi penelitian dalam PTS ini adalah seluruh guru di SMK Negeri 1 Sidenreng, yakni sebanyak 30 orang. Karena keterbatasan waktu dan biaya, maka yang dijadikan subjek dalam penelitian ini hanya 2 orang penjaskes. Adapun yang menjadi variabel dalam penelitian ini adalah:

1. Variabel bebas $(\mathrm{X})$ atau variabel yang mempengaruhi dalam penelitian ini adalah "Kegiatan Pembelajaran"

2. Variabel terikat (Y) atau variabel yang dipengaruhi dalam penelitian ini adalah

"Peningkatan Keterampilan Guru Dalam Mewujudkan pendidikan karakter bangsa".

Teknik pengumpulan data dalam penelitian ini diperoleh melalui observasi dan catatan data lapangan, wawancara, hasil tes dan catatan hasil refleksi/diskusi yang dilakukan oleh peneliti dan mitra peneliti. Penentuan teknik tersebut didasarkan ketersediaan sarana dan prasarana dan kemampuan yang dimiliki peneliti dan mitra peneliti. Adapun teknik-teknik pengumpulan data tersebut adalah sebagai berikut:

a. Penilaian Pre Tes dan Post Tes

b. Observasi dan catatan data lapangan

c. Catatan hasil refleksi

Adapun, analisis/pembahasan data dalam PTS ini dilakukan sejak awal, artinya analisis data dilakukan tahap demi tahap atau siklus demi siklus. Kegiatan analisis data akan dilakukan mengacu pada pendapat Rochiati Wiriaatmaja, (2005:135-151) dengan melakukan catatan refleksi, yakni pemikiran yang timbul pada saat mengamati dan merupakan hasil proses membandingkan, mengkaitkan atau menghubungkan data yang ditampilkan dengan data sebelumnya atau dengan teori-teori yang relevan.

Maka, permasalahan yang diangkat dalam Penelitian Tindakan Sekolah ini adalah belum semua guru mampu mewujudkan pendidikan karakter bangsa dalam pembelajaran yang dapat membuat siswa aktif dan sekaligus menyenangkan, sehingga akan berpengaruh terhadap pengembangan nilai-nilai karakter bangsa.

Pengawas sekolah akan memberikan bimbingan berkelanjutan bimbingan pengawas berkelanjutan dapat meningkatkan kemampuan guru dalam mewujudkan pendidikan karakter bangsa dalam kegiatan belajar mengajar penjaskes di SMK Negeri 1 Sidenreng tahun pelajaran 2014/2015. Pengawas sekolah akan mensupervisi pembelajaran untuk mewujudkan pendidikan karakter bangsa. 
Lalu, pengawas sekolah mengamati nilai-nilai pembangunan karakter bangsa yang berkembang (muncul) pada saat diterapkannya pembelajaran di kelas. Adapun nilai-nilai pembangunan karakter bangsa yang akan lebih memfokuskan pada 4 nilai yang memiliki yakni (1) Kerjasama atau Gotong Royong; (2) Kerja Keras; (3) Menghargai; (4) Bertangung Jawab; dan (5) Adil.

\section{HASIL PENELITIAN}

Dari hasil penilaian RPP diperoleh data bahwa kedua RPP yang dibuat oleh guru yang menjadi subjek penelitian ternyata belum dapat dikategorikan baik, karena nilai rata-rata hanya mencapai 30. diperoleh pada tabel 1. data nilai RPP sebesar 30 (kurang baik), nilai karakter bangsa sebesar 30 (kurang baik) pada siklus I ini. Dilihat dari unsur kejelasan tujuan, pemilihan dan pengorganisiran materi, kejelasan skenario, penggunaan metode dan alat evaluasi yang digunakan sudah masuk kategori baik. Namun masih ada yang terdapat dalam RPP ini belum jelas pemilihan media yang sudah variatif.

Sebagai implikasi dari hasil refleksi pada siklus ini, pada siklus berikutnya akan ditampilkan metode dan media pembelajaran yang lebih variatif serta dapat merangsang atau memotivasi siswa untuk terlibat secara aktif sehingga diharapkan akan lebih banyak nilai-nilai pengembangan karakter bangsa yang bisa diserap peserta didik.

Berdasarkan hasil refleksi menunjukkan bahwa tingkat pemahaman dan keterampilan guru dalam menyusun RPP berkarakter bangsa masih rendah sehingga berimplikasi pada masih rendahnya keterlaksanaan nilai pembangunan karakter bangsa. Maka fokus PTS pada siklus ini adalah meningkatkan kemampuan guru dalam penyusunan RPP yang mengedepankan penanaman nilai karakter bangsa. Sama halnya pada siklus I, perlakuan pada siklus II inipun terdapat empat tahap, yakni:

1. Perencanaan

2. Pelaksanaan Tindakan

3. Pengamatan

4. Refleksi

Berdasarkan data dari hasil penilaian RPP diperoleh data bahwa kedua RPP yang dibuat oleh guru yang menjadi subjek penelitian ternyata sudah dapat dikatagorikan sangat baik, karena nilai rata-rata mencapai 91. Lalu, berdasarkan hasil penilaian yang diperoleh pada pengolahan data nilai RPP sebesar 43 (sangat baik), nilai karakter bangsa sebesar 43 (sangat baik) pada siklus II ini.

Berdasarkan hasil survei dalam kegiatan PBM tersebut tampak ada peningkatan keterlaksanaan Nilai Pembangunan Karakter Bangsa. Ini terlihat dari jumlah indikator yang terpenuhi. Dalam mapel penjaskes pada siklus I dari 5 indikator karakter bangsa hanya tecapai 75\%. Dan pada siklus II dari 5 indikator karakter kebangsaan telah meningkat kemunculannya mencapai 91\%. Peningkatan pencapaian keterlaksanaan nilai pembangunan karakter bangsa dalam PBM ini disebabkan karena guru-guru yang menjadi subyek penelitian telah berupa menerapkan metode pembelajaran yang variatif dan melibatkan siswa.

Berdasarkan hasil refleksi tersebut, pada siklus berikutnya akan ditampilkan media pembelajaran yang lebih menarik dan variatif serta dapat merangsang atau memotivasi siswa untuk terlibat secara aktif dan diharapakan akan semakin banyak nilai pembangunan karakter bangsa yang terlaksana.

Berdasarkan dari dua siklus yang telah dilakukan, maka hasil penelitian menunjukkan bahwa pengintegrasian pembangunan atau pendidikan karakter bangsa ke dalam semua mata 
pelajaran bukan merupakan sesuatu yang tidak dapat dilakukan, tetapi justru merupakan hal penting yang harus dilakukan. Bahkan selanjutnya pengintegrasian pembangunan atau pendidikan karakter bangsa harus terdapat dalam visi, misi, dan tujuan sekolah. Persoalan yang timbul dalam kaitannya dengan muatan pembangunan atau pendidikan karakter bangsa di kalangan guru (terutama di daerah) saat ini adalah kekhawatiran munculnya format RPP dan Silabus yang baru yang harus memasukkan pembangunan nilai-nilai karakter bangsa tersebut. Hal ini penting untuk kita pikirkan bersama agar kita tidak terjebak pada berbagai konstruksi yang tidak menyentuh akar persoalan yang kita hadapi.

Hasil penelitian ini sekalipun sangat sederhana menunjukkan bahwa pengintegrasian pembangunan atau pendidikan karakter bangsa ke dalam semua mata pelajaran tidak mesti dilakukan dengan mengadakan perubahan pada format atau komponen RPP yang harus dibuat oleh guru. Ini penting dilakukan untuk menghindari sikap apatis guru-guru terhadap perubahan kurikulum yang disebabkan perubahan kurikulum yang terlalu cepat.

Kita mesti bercermin bahwa rendahnya karakter bangsa kita saat ini adalah warisan yang banyak disumbangkan oleh model pendidikan karakter bangsa masa sebelum reformasi yang lebih banyak menekakan indoktrinasi dan penuh dengan muatan 'kekuasaan'. Oleh karena itu, mari kita benahi pembangunan atau pendidikan karakter bangsa dengan peningkatan keterampilan guru dalam mengelola kegiatan belajar mengajar dengan menerapkan pendekatan CTL, PAIKEM dan lainnya yang menghindari praktek indoktrinasi. Dan yang tak kalah penting kita harus segera melakukan pembenahan sarana prasarana pendidikan sehingga eksperimen guru untuk menerapkan pendekatan pembelajaran yang efektif dan menyenangkan tersebut akan mudah dilakukan.

\section{SIMPULAN}

Berdasarkan hasil pelaksanaan penelitian tindakan sekolah (PTS) mengenai peningkatan kemampuan guru penjaskes dalam menyusun RPP memuat karakter bangsa berlangsung selama 2 siklus penelitian dapat disimpulkan bahwa:

1. Bimbingan pengawas berkelanjutan dapat meningkatkan kemampuan guru dalam mewujudkan pendidikan karakter bangsa dalam kegiatan belajar mengajar penjaskes di SMK Negeri 1 Sidenreng tahun pelajaran 2014/2015, maka keterlaksanaan nilai-nilai Pendidikan Karakter Bangsa telah meningkat. Dari hasil penelitian menunjukkan bahwa pada siklus I nilai rata-rata pada RPP berkarakter kebangsaaan mencapai 30 (kurang baik), dan pada siklus II telah mencapai 43 (sangat baik) terdapat peningkatan nilai yang cukup signifikan sebesar 13 dari siklus I. Dan keterlaksanaan pendidikan karakter bangsa dalam kegiatan belajar mengajar telah berjalan sangat efektif.

2. Bimbingan pengawas berkelanjutan berpengaruh positif terhadap peningkatan kemampuan guru dalam mewujudkan pendidikan karakter bangsa dalam kegiatan belajar mengajar penjaskes di SMK Negeri 1 Sidenreng tahun pelajaran 2014/2015 dalam hal ini dapat berjalan efektif, maka keterlaksanaan nilai-nilai Pendidikan Karakter Bangsa telah meningkat.

\section{SARAN}

Adapun saran yang dapat penulis sampaikan adalah:

1) Bimbingan pengawas berkelanjutan perlu terus dilaksanakan dalam kegiatan Pembelajaran Aktif, Inovatif, Kreatif, Efektif dan Menyenangkan. Aktivits dan hasil belajar siswa serta bagi terlaksananya nilai-nilai pembangunan karakter bangsa harus dilaksanakan secara terus menerus dalam PBM. 
2) Guru-guru harus dapat mengenali dan menggunakan berbagai metode, strategi dan/atau model pembelajaran; sehingga mempunyai banyak pilihan untuk dapat menerapkan pendekatan model pembelajaran dalam kegiatan belajar mengajar.

3) Selain keterampilan memilih model pembelajaran, guru yang profesional juga hendaknya dapat memilih media yang tepat untuk menyampaikan materi pembelajaran. Oleh karena itu, guru juga dituntut memiliki kreativitas dan keterampilan memilih media pembelajaran yang tepat.

4) Pembangunan karakter bangsa merupakan kegiatan yang harus terus di laksanakan terutama di lingkungan sekolah. Oleh karena itu, perlu terus digali model implikasi pembangunan karakter bangsa di sekolah baik secara terintegrasi melalui PBM maupun melalui model lainnya.

\section{Refference}

Bahan Workshop KTSP, Pengembangan Bahan Ajar dan Media, Depdinas 2007

Bobbi DePorte \& Mike Hernacki. (2000) Quantum Learning Membiasakan Belajar Nyaman dan Menyenangkan. Kaifa. Bandung

Danial, Endang AR., Dr. H. M.Pd. (2003) Penelitian Tindakan Kelas. Direktorat PLP, Dirjendikdasmen, Depdiknas. Jakarta

Depdiknas. (2002) Pedoman Pembangunan Karakter Bangsa di Sekolah Lanjutan Tingkat Pertama, Direktorat Pendidikan Dasar dan Menengah, Direktoral Pendidikan Lanjutan Pertama. Jakarta

Depdiknas. (2003) Pendekatan Kontekstual (Contextual Teaching and Learning). Direktorat Pendidikan Dasar dan Menengah, Direktoral Pendidikan Lanjutan Pertama. Jakarta

Depdiknas. (2005) Paket Pelatihan 1 Peningkatan Mutu Pendidikan Dasar melalui Manajemen Berbasis Sekolah, Peran Serta Masyarakat, Pembelajaran Aktif, Kreatif, Efektif dan Menyenangkan. Depdiknas. Jakarta

Depdiknas. (2009) Draf Pedoman Pengembangan Pendidikan Budaya Dan Karakter Bangsa . Depdiknas. Jakarta

Indonesia (2005). Undang-Undang Republik Indonesia Nomor 14 Tahun 2005 Tentang Guru dan Dosen.

Hasibuan dan Moedjino. (1996) Proses Belajar Mengajar. Bandung: Remadja Karya.

Hidayat, Kosadi, dkk.. (1987) Strategi Belajar Mengajar Bahasa Indonesia. Bandung: Bina Cipta.

Munandir. (2001) Ensiklopedia Pendidikan. Malang: UM Press

Pemerintah RI (2010) “Kebijakan Nasional Pembanguan Karakter Bangsa 2010-2025”

Silberman, Melvin L (2002). Active Learning, 101 Strategi Pembelajaran. Yappendis. Yogyakarta

Sudirman, dkk. (1987) Ilmu Pendidikan. Bandung: Remadja Karya CV.

Sudjana. (1992) Metoda Statistik. Bandung: Tarsito.

Suriasumantri, Jujun S. (1999) Filsafat Ilmu Sebuah Pengantar Populer. Jakarta: Pustaka Sinar Harapan.

Suwarsih Madya. (2007) Penelitian Tindakan Kelas. www.ktiguru.Org

Suhardjono, A. Azis Hoesein, dkk (1995). Pedoman penyusunan KTI di Bidang Pendidikan dan Angka Kredit Pengembangan Profesi Guru. Digutentis, Jakarta : Diknas

Suhardjono. 2005. Laporan Penelitian Eksperimen dan Penelitian Tindakan Kelas sebagai KTI, makalah pada Pelatihan Peningkatan Mutu Guru di LPMP Makasar, Maret 2005

Suhardjono. 2009. Tanya jawab tentang PTK dan PTS, naskah buku.

Suharsimi, Arikunto. (1996) Prosedur Penelitian Suatu Pendekatan Praktek. Jakarta: Rineka Cipta.

Suharsimi, Arikunto. 2002. Penelitian Tindakan Kelas, Makalah pada Pendidikan dan Pelatihan (TOT) Pengembangan Profesi bagi Jabatan Fungsionla Guru, 11-20 Juli 2002 di Balai penataran Guru (BPG) Semarang.

Suharsimi, Suhardjono dan Supardi. 2006. Penelitian Tindakan Kelas. Jakarta : PT Bumi Aksara 